\title{
ORGANIZATIONAL AND ECONOMIC CONDITIONS FOR THE FUNCTIONING OF THE STATE FORESTS NATIONAL FOREST HOLDING
}

UWARUNKOWANIA ORGANIZACYJNO-EKONOMICZNE FUNKCJONOWANIA PAŃSTWOWEGO GOSPODARSTWA LEŚNEGO LASY PAŃSTWOWE

\begin{abstract}
Objective

The purpose of this article was to examine whether the spending of funds at the disposal of the State Forests National Forest Holding corresponded to the tasks of forest management imposed on this institution under the provisions of applicable law and whether it was justified in the context of the principle of rational management of public funds.

\section{Methods}

The research was based on the analysis of secondary data collected by the Directorate General of State Forests, official statistical data, post-audit information of the Supreme Audit Office and literature covering the research area.

\section{Results}

The results of research carried out on the basis of data from 2011-2018 showed that the overall property and financial situation of the State Forests in the analyzed period was favorable due to the fact that each year the institution recorded a significant net profit.
\end{abstract}




\section{Discussion}

The measures implemented by the State Forests were generally in line with the model for sustainable forest management set out in the Act on Forest however in the case of capital expenditure for fixed assets, they were not directly related to forest management. The principle of rational management of public funds was not always fully applied. Hence, the economic account should constitute the basis for investment activities conducted by the State Forests.

\section{STRESZCZENIE}

\section{Cel}

Celem niniejszego artykułu było zbadanie, czy wydatkowanie środków będących w dyspozycji Państwowego Gospodarstwa Leśnego Lasy Państwowe odpowiadało zadaniom w zakresie gospodarki leśnej nałożonym na tę instytucję na podstawie przepisów obowiązującego prawa i czy było ono uzasadnione w kontekście zasady racjonalnego gospodarowania środkami publicznymi.

\section{Metody}

Badania oparto na analizie danych wtórnych zebranych przez Dyrekcję Generalną Lasów Państwowych, oficjalnych danych statystycznych, informacji pokontrolnej Najwyższej Izby Kontroli oraz literaturze obejmującej obszar badań.

\section{Wyniki}

Wyniki badań przeprowadzonych na podstawie danych z lat 2011-2018 wykazały, że ogólna sytuacja majątkowa i finansowa Lasów Państwowych w analizowanym okresie była korzystna ze względu na fakt, że co roku wspomniana instytucja odnotowywała znaczący zysk netto.

\section{Omówienie}

Działania realizowane przez Lasy Państwowe były zasadniczo zgodne z modelem zrównoważonej gospodarki leśnej określonym w ustawie o lasach, jednak w przypadku ponoszenia nakładów inwestycyjnych na środki trwałe niezwiązane bezpośrednio z gospodarką leśną, zasada racjonalnego zarządzania środkami publicznymi nie zawsze miała pełne zastosowane. Stąd też rachunek ekonomiczny powinien stanowić podstawę do prowadzenia działalności inwestycyjnej przez Lasy Państwowe.

KEYWORDS: rational management, public funds, state forests, organizational and economic conditions, forest management.

SŁowA KLUCzowe: racjonalne gospodarowanie, środki publiczne, lasy państwowe, uwarunkowania organizacyjno-ekonomiczne, gospodarka leśna. 


\section{WPROWADZENIE}

Państwową jednostką organizacyjną, która zarządza lasami stanowiącymi własność Skarbu Państwa, jest Państwowe Gospodarstwo Leśne Lasy Państwowe (dalej: LP) (Tyburek, 2011, s. 118; Szramka, Adamowicz, 2017, s. 355). Lasy będące w zarządzie LP zajmują powierzchnię 7.115 tys. ha, co stanowi $77 \%$ powierzchni lasów w Polsce (GUS, 2019, s. 36). Zgodnie ze sprawozdaniem finansowo-gospodarczym za 2018 r. jednostki organizacyjne LP wygenerowały przychody w kwocie prawie 9,79 mld zł, z czego kwota 537,1 mln zł stanowiła zysk netto, a główne źródło przychodów pochodziło ze sprzedaży surowca drzewnego (DGLP, 2019, s. 13). W konsekwencji, prowadząc działalność na zasadzie samodzielności finansowej, LP są największym w Unii Europejskiej podmiotem zarządzającym lasami publicznymi (Maćkowiak, 2016, s. 114; Bieluk, Leśkiewicz, 2017, s. 128). W ramach tego zarządu, poza prowadzeniem ewidencji majątku Skarbu Państwa i ustalaniem jego wartości, LP prowadzą gospodarkę leśną, gospodarkę gruntami i innymi nieruchomościami oraz ruchomościami związanymi z gospodarką leśną, takimi jak: tartaki i składnice drewna, gospodarstwa rybackie czy baza szkoleniowo-wypoczynkowa (Szczypa, 2016, s. 176; Kruk, 2017, s. 184). Oprócz działalności gospodarczej, LP realizują również zadania z zakresu ochrony zasobów leśnych, co implikuje swego rodzaju dualizm prawnoorganizacyjny tej instytucji (NIK, 2015, s. 6).

Podstawowym aktem prawnym regulującym działalność LP, w tym w szczególności strukturę organizacyjną oraz sposób prowadzenia gospodarki finansowej, jest ustawa z 28 września 1991 r. o lasach (Dz.U. z 2020 r. poz. 6 ze zm.). Zgodnie $\mathrm{z}$ art. 6 ust. 1 pkt 1 tej ustawy gospodarka leśna jest pojmowana jako działalność leśna w zakresie urządzania, ochrony i zagospodarowania lasu, utrzymania i powiększania zasobów leśnych, gospodarowania zwierzyną, pozyskiwania (z wyjątkiem skupu) drewna, żywicy, choinek, kory, karpiny, igliwia, zwierzyny oraz płodów runa leśnego, a także sprzedaż tych produktów oraz realizacja pozaprodukcyjnych funkcji lasu. Działalnością LP kieruje Dyrektor Generalny LP za pomocą dyrektorów właściwych regionalnych dyrekcji LP. Z kolei w skład regionalnych dyrekcji wchodzą nadleśnictwa stanowiące podstawowe jednostki organizacyjne LP. Koszty utrzymania Dyrekcji Generalnej LP oraz dyrekcji regionalnych LP pokrywane są z wpłat obciążających koszty działalności nadleśnictw (Radecki, 2017, s. 453; Kosikowski, 2006, 
s. 216). Nadleśniczy samodzielnie prowadzą gospodarkę leśną w nadleśnictwach na podstawie planów urządzenia lasu oraz odpowiadają za stan lasów (Rakoczy 2018, s. 55; Pakuła 2011, s. 79). Nadzór nad LP sprawuje Minister Środowiska, jednakże zarówno samo pojęcie nadzoru, jak i środki kontroli nadzorowanej działalności nie zostały w ustawie precyzyjnie zdefiniowane, co w konsekwencji powoduje, że zakres dyskrecjonalnych kompetencji Dyrektora Generalnego LP jest relatywnie szeroki (Habuda, Radecki 2016, s. 264). W związku z tym, przy tak dużej skali i swobodzie działania LP, prowadzenie gospodarki finansowej przez tę instytucję w zgodzie z zasadą racjonalnego gospodarowania środkami publicznymi, tj. ich rozdysponowanie w sposób celowy i oszczędny, dążąc przy tym do uzyskiwania najlepszych efektów z danych nakładów, stanowi zagadnienie o doniosłym znaczeniu (Szołno-Koguc, 2007, s. 63).

\section{METODY BADAWCZE}

Mając na uwadze ważność wskazanego powyżej problemu oraz długookresowy charakter działalności LP, sprowadzający się nie tylko do działań stricte ekonomicznych, lecz także przyrodniczych, społecznych i kulturowych (Sadowska, 2016, s. 401), celem niniejszego artykułu była próba analizy i oceny funkcjonowania LP na przykładzie wybranych aspektów organizacyjno-ekonomicznych w zakresie działalności podstawowej oraz działalności administracyjnej LP. Przede wszystkim podjęto próbę udzielenia odpowiedzi na następujące pytanie badawcze: czy wydatkowanie środków finansowych będących w dyspozycji LP odpowiadało zadaniom z zakresu gospodarki leśnej nałożonym na przedmiotową instytucję na mocy przepisów powszechnie obowiązującego prawa i czy znajdowało to swoje uzasadnienie w kontekście zasady racjonalnego gospodarowania środkami publicznymi?

W artykule zastosowano w głównej mierze następujące metody: analizę źródłową, analizę logiczną i analizę porównawczą. Podstawę badań teoretycznych stanowiły obowiązujące regulacje normatywne oraz literatura z zakresu obszaru badawczego, natomiast badania empiryczne w zakresie gospodarki finansowej LP zostały dokonane na podstawie danych wtórnych pochodzących z Generalnej Dyrekcji LP w formie rocznych spra- 
wozdań finansowo-gospodarczych, informacji pokontrolnych Najwyższej Izby Kontroli oraz oficjalnych danych statystycznych. W celu uzyskania miarodajnych wyników przeprowadzonych analiz badaniem objęto lata 2011-2018.

\section{WYNIKI}

Zasadniczym celem LP jest prowadzenie gospodarki leśnej według zasad powszechnej ochrony lasów, trwałości ich utrzymania, ciągłości i zrównoważonego wykorzystania wszystkich funkcji lasów oraz powiększania zasobów i upraw leśnych. Przedmiotowy cel LP realizują poprzez prowadzenie trwale zrównoważonej gospodarki leśnej polegającej w szczególności na kształtowaniu struktury lasów i ich wykorzystaniu w sposób zapewniający trwałe zachowanie ich walorów biologicznych, wysokiej produkcyjności oraz potencjału regeneracyjnego (Dyduch, 2016, s. 78-79). Stosownie do art. 7 ust. 1 ustawy o lasach, trwale zrównoważona gospodarka leśna jest prowadzona według planu urządzenia lasu lub uproszczonego planu urządzenia lasu, z uwzględnieniem m.in. zachowania lasów oraz korzystnego ich wpływu na środowisko naturalne i zdrowie człowieka, ochrony lasów, wód, gleb i terenów szczególnie narażonych na zanieczyszczenie, a także produkcji, na zasadzie racjonalnej gospodarki, drewna oraz surowców i produktów ubocznego użytkowania lasu (Radecki, 2017, s. 84). Lasy Państwowe prowadzą działalność na zasadzie samodzielności finansowej i pokrywają koszty działalności z własnych przychodów (Kropiewnicka, Ostrowiecki, 2014, s. 224; Maćkowiak, 2016, s. 114). W związku z tym, w celu optymalizacji wykorzystania publicznych środków finansowych, działalność gospodarcza LP, włączając w to działalność inwestycyjną, powinna być prowadzona na bazie rachunku ekonomicznego (NIK, 2015, s. 23).

Jak wskazano na wstępie, głównym źródłem przychodów LP jest sprzedaż drewna. $\mathrm{W}$ badanym okresie najniższe przychody ze sprzedaży tego surowca osiagnięto w 2013 r. (tj. 6.297.759,3 tys. zł), a najwyższe w $2018 \mathrm{r}$. (tj. 8.544.286,7 tys. zł), co stanowiło odpowiednio $86,9 \%$ i $87,3 \%$ przychodów LP ogółem (zob. wykres 1). Pozostałe źródła przychodów, takie jak np. gospodarka łowiecka czy sprzedaż materiałów i przychody pozostałej sprzedaży, miały istotnie mniejsze znaczenie. 
Wykres 1.

Zmiany wysokości przychodów ogółem oraz przychodów ze sprzedaży drewna w LP w latach 2011-2018 (w mld zł)

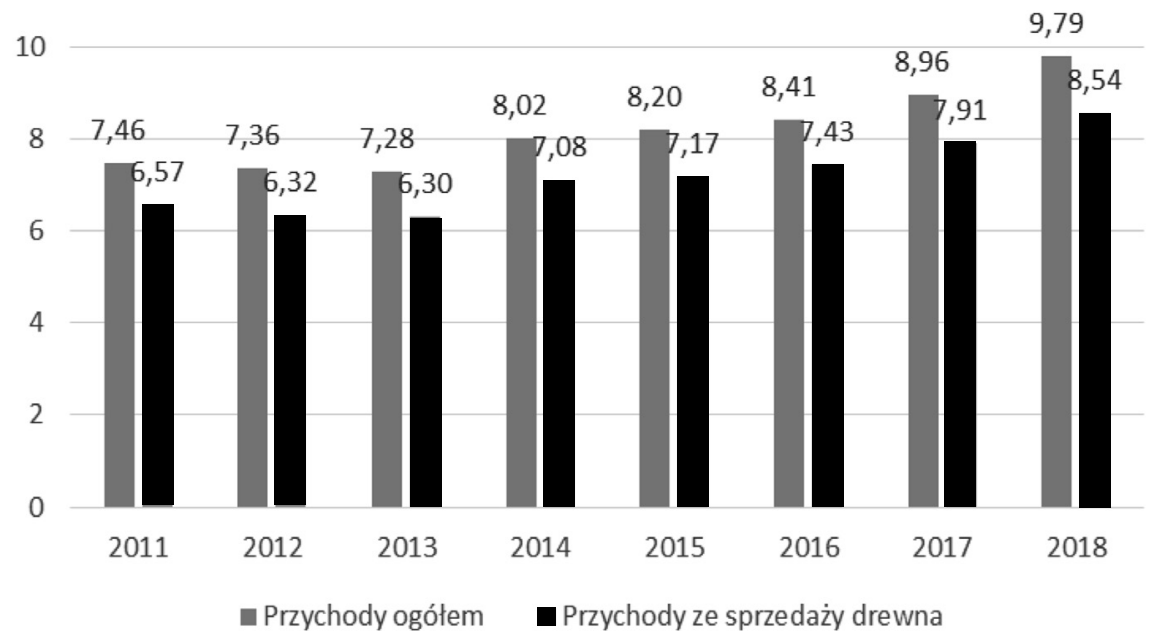

Źródło: opracowanie własne na podstawie sprawozdań finansowo-gospodarczych LP za lata 2011-2018.

Jak wynika $\mathrm{z}$ danych zobrazowanych na wykresie 1, w latach 2011-2013 przychody LP ze sprzedaży surowca drzewnego zmniejszyły się odpowiednio z 6.566.962,2 tys. zł do 6.297.759,3 tys. zł. Wyraźne zwiększenie przychodów w tym zakresie można było natomiast zaobserwować w latach 2014-2018, tj. LP uzyskały przychody ze sprzedaży drewna w kwocie 7.081.869,3 tys. zł w 2014 r., natomiast w 2018 r. kwota $\mathrm{z}$ tego tytułu wyniosła $9.791 .575,8$ tys. zł. Zmiany wysokości przychodów w badanym okresie występowały na skutek prowadzenia przez LP polityki stopniowego zwiększania podaży drewna - z 35,08 $\mathrm{mln} \mathrm{m}^{3}$ w 2011 r. do 44,69 $\mathrm{mln} \mathrm{m}^{3}$ w 2018 r. (GUS, 2019, s. 329). Obserwowane różnice w przychodach nie były istotnie skorelowane ze zmianami przeciętnej ceny drewna w danym roku - a zatem czynnika nie do końca zależnego od LP. Tytułem przykładu można wskazać, że w 2011 r. przeciętna cena drewna za $1 \mathrm{~m}^{3}$ kształtowała się na poziomie 188,27 zł, natomiast w 2018 r. była niewiele wyższa, gdyż wynosiła 191,79 zł (GUS, 2019, s. 105). Co ważne, zgodnie $\mathrm{z}$ danymi zawartymi w sprawozdaniach finansowo-gospodarczych LP za lata 
2011-2018 w analizowanym okresie podmiot ten corocznie odnotowywał znaczny zysk netto, który wynosił: 829,14 mln złw 2011 r., 259,60 mln zł w 2012 r., $304,97 \mathrm{mln}$ zł w 2013 r., $421,70 \mathrm{mln}$ zł w 2014 r., 382,16 mln zł w 2015 r., 404,03 mln zł w 2016 r., 435,1 mln zł w 2017 r. oraz 537,1 mln zł w 2018 r.

W świetle zasady racjonalnego gospodarowania środkami publicznymi należy stwierdzić, że wydatkowanie tak znacznych środków publicznych przez LP, w tym prowadzenie działalności inwestycyjnej, powinno być ściśle związane ze wzmocnieniem podstawowego źródła przychodów oraz zmierzać do osiągnięcia optymalnych efektów przy kosztach określonych na racjonalnym poziomie. $\mathrm{W}$ badanym okresie poddano więc analizie koszty działalności podstawowej LP (tj. przede wszystkim hodowli i ochrony lasu oraz pozyskania i zrywki drewna) do kosztów działalności administracyjnej, obejmującej głównie utrzymanie Służby Leśnej, a także pozostałą działalność administracyjną nadleśnictw (DGLP, 2019, s. 9), co prezentuje wykres 2. Warto przy tym nadmienić, że obie kategorie kosztów każdorocznie łącznie stanowiły zdecydowanie największą część kosztów ogółem LP.

Wykres 2.

Zmiany wysokości kosztów działalności podstawowej i kosztów działalności administracyjnej LP w latach 2011-2018 (w mld zl)

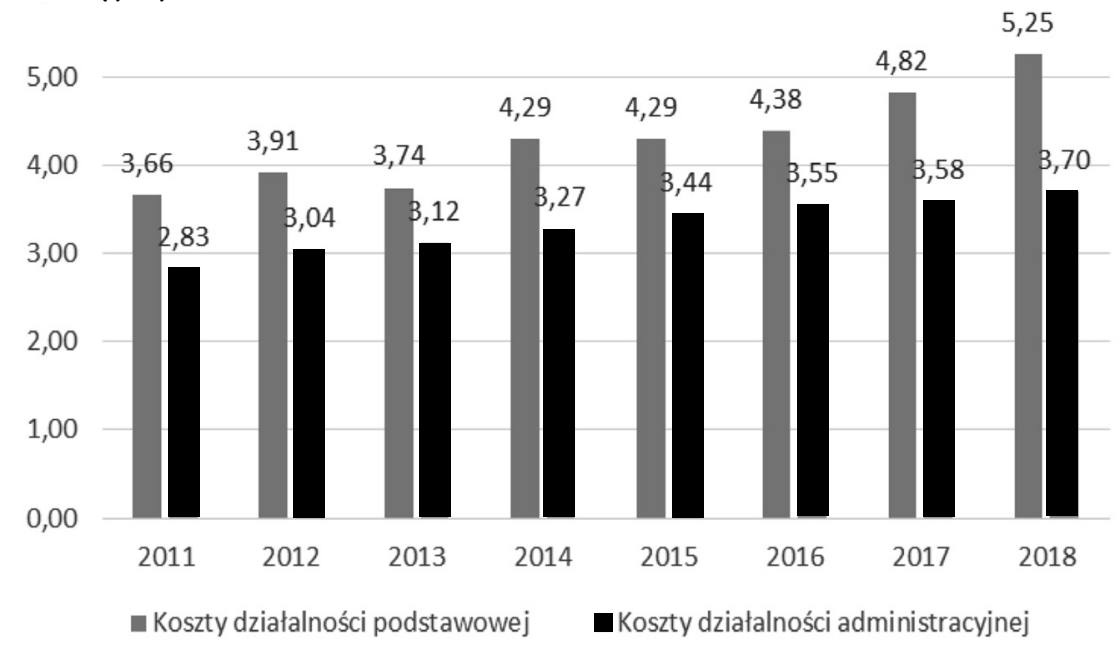

Źródło: opracowanie własne na podstawie sprawozdań finansowo-gospodarczych LP za lata 2011-2018. 
Jak można zatem zaobserwować na wykresie 2, pomimo pewnych zmian dynamiki wzrostu kosztów działalności podstawowej LP, w latach 2011-2018 nastąpił dynamiczny i stabilny wzrost kosztów działalności administracyjnej. W całym badanym okresie koszty działalności administracyjnej LP były relatywnie wysokie. Tytułem przykładu można wskazać, że w 2013 r. wyniosły one 3.119,55 mln zł, natomiast koszty działalności podstawowej LP wyniosły $3.742,97 \mathrm{mln}$ zł, a więc były to kwoty porównywalne. W tym kontekście warto zwrócić uwagę na fakt, że analiza stanu zatrudnienia w LP w latach 2011-2018 wykazała wyraźne zwiększenie zatrudnienia ogółem w tej instytucji. W 2018 r. zatrudnienie ogółem w LP wyniosło 26414 osób i w stosunku do 2011 r. było ono wyższe o 1616 osób, przy czym pracownicy Służby Leśnej stanowili zdecydowanie największą grupę zatrudnionych (GUS, 2019, s. 330). Równolegle w tym samym okresie nastąpił dynamiczny wzrost wynagrodzeń w LP, które były prawie dwukrotnie wyższe od wynagrodzeń w gospodarce narodowej. Wykres 3 prezentuje zmiany wysokości przeciętnego wynagrodzenia miesięcznego ogółem w LP w poszczególnych latach analizowanego okresu na tle analogicznej kategorii danych odnoszących się do gospodarki narodowej.

Wykres 3.

Zmiany wysokości przeciętnego wynagrodzenia miesięcznego ogółem w LP oraz w gospodarce narodowej w latach 2011-2018 (w zl)

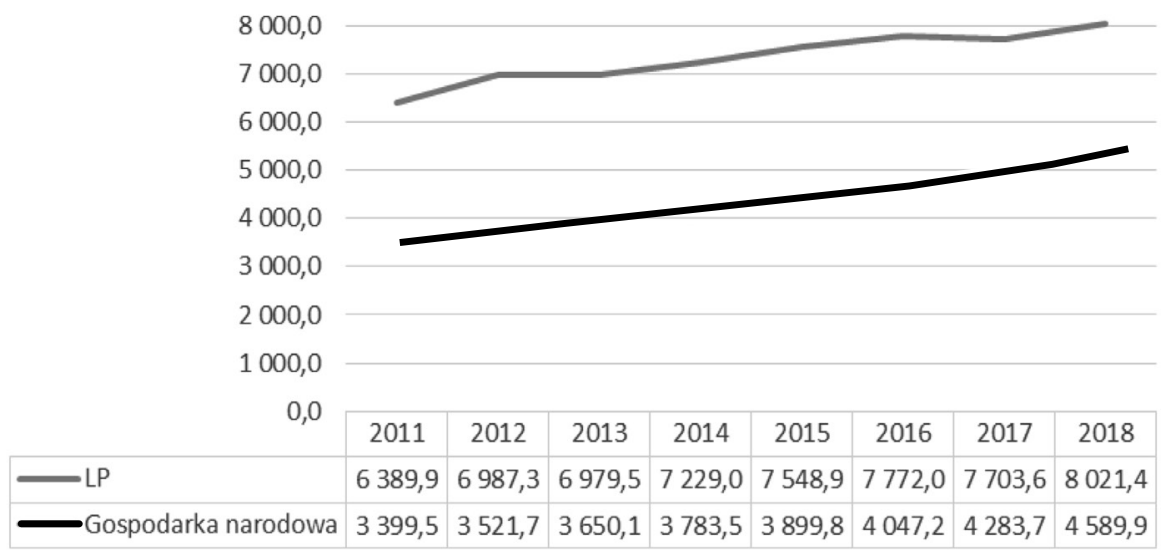

$\longrightarrow$ LP Gospodarka narodowa

Źródło: opracowanie własne na podstawie www.stat.gov.pl (dostęp 12.02.2020). 
Analizując działalność inwestycyjną LP, należy stwierdzić, że w latach 2011-2013 nakłady na budowę środków trwałych wzrosły z 943,6 mln zł do 1.123,0 mln zł. Z kolei w latach 2014-2016 można było zaobserwować znaczący spadek tych nakładów do kwoty 573,6 mln zł (GUS, 2019, s. 328). Równocześnie warto zauważyć, że $\mathrm{z}$ analizy wysokości ponoszonych rokrocznie przez LP kosztów ochrony i hodowli lasu, które są kluczowe dla właściwego prowadzenia trwale zrównoważonej gospodarki leśnej (Kruk, 2017, s. 173-174), wynika, że począwszy od 2011 r. (849,9 mln zł), wykazywały one wyraźne tendencje wzrostowe, by w 2018 r. osiągnąć wartość 1.176,6 mln zł (wykres 4).

Wykres 4.

Zmiany wysokości kosztów hodowli i ochrony lasu oraz nakładów na budowę środków trwałych w LP w latach 2011-2018 (w mln zl)

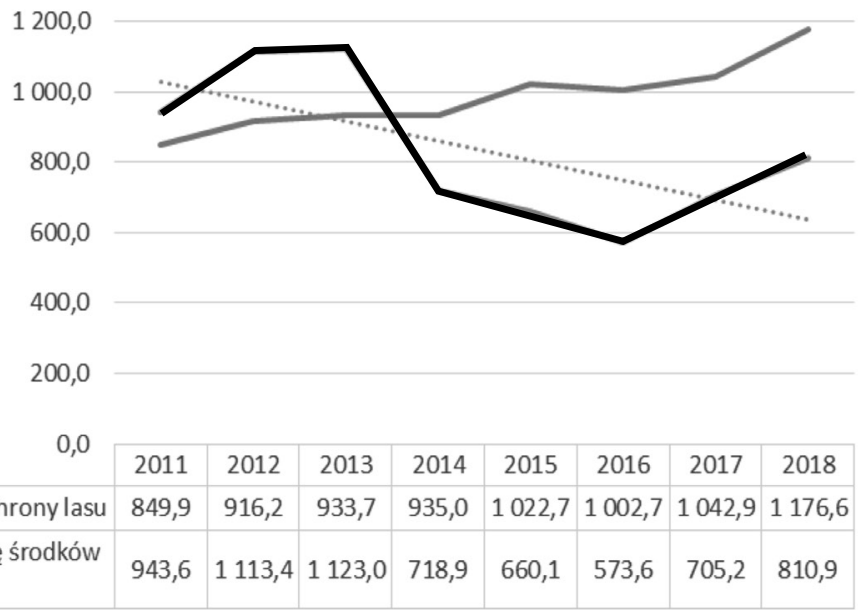

\begin{tabular}{|c|c|c|c|c|c|c|c|c|}
\hline & 2011 & 2012 & 2013 & 2014 & 2015 & 2016 & 2017 & 2018 \\
\hline -Koszty hodowli i ochrony lasu & 849,9 & 916,2 & 933,7 & 935,0 & 1022,7 & 1002,7 & 1042,9 & 1176,6 \\
\hline $\begin{array}{l}\text { Nakłady na budowę środków } \\
\text { trwałych }\end{array}$ & 943,6 & 1113,4 & 1123,0 & 718,9 & 660,1 & 573,6 & 705,2 & 810,9 \\
\hline
\end{tabular}

Koszty hodowli i ochrony lasu

- Nakłady na budowę środków trwałych

Źródło: opracowanie własne na podstawie www.stat.gov.pl (dostęp 12.02.2020).

Przedstawiony na wykresie 4 pozytywny trend w zakresie zwiększenia wydatków poniesionych na hodowlę i ochronę lasu przy jednoczesnej - co do zasady - redukcji nakładów na budowę środków trwałych w LP jest zbieżny z uwagami i wnioskami Najwyższej Izby Kontroli wyartykułowanymi 
w tym przedmiocie w wystąpieniach pokontrolnych skierowanych do osób kierujących jednostkami organizacyjnymi LP, które w latach 2014-2015 zostały poddane kontroli stanu majątkowo-finansowego oraz efektywności prowadzonej działalności gospodarczej. W trakcie wykonywania czynności kontrolnych stwierdzone zostały przypadki ponoszenia przez LP wysokich wydatków na przedsięwzięcia inwestycyjne niemające ścisłego związku z realizacją zadań wynikających z przepisów obowiązującego prawa.

O ile celowość ponoszenia przez LP wydatków inwestycyjnych na poprawę jakości dróg w lasach nie budziła zastrzeżeń NIK, o tyle zakwestionowane zostały niepoparte analizami ekonomicznymi wysokie nakłady na zakup, modernizację i remonty niektórych budynków administracyjno-biurowych, ośrodków szkoleniowo-wypoczynkowych, kwater myśliwskich oraz budynków mieszkalnych, w których standard wykonywanych prac był niejednokrotnie bardzo wysoki. Jako przykłady takich działań wskazano zakup nieruchomości z przeznaczeniem na nową siedzibę Dyrekcji Generalnej LP w Warszawie (nabycie prawa użytkowania wieczystego trzech działek gruntów oraz prawa własności trzech budynków za kwotę ponad 62,4 mln zł) czy rozbudowę Ośrodka Wypoczynkowego „Leśnik” w Łagowie (prace budowlane obejmowały dobudowę sali konferencyjnej z zapleczem oraz pokojami hotelowymi o łącznej powierzchni użytkowej $473 \mathrm{~m}^{2}$ za kwotę ponad 3 mln zł) (NIK, 2015, s. 24-27).

\section{WNIOSKI}

Wyniki badań przeprowadzonych na podstawie danych $\mathrm{z}$ lat 2011-2018 wykazały, że ogólna sytuacja finansowo-majątkowa LP w analizowanym okresie była korzystna. Corocznie instytucja ta odnotowywała istotny zysk netto, choć w niektórych latach wysokość kwot wypracowanego zysku różniła się w sposób znaczący (np. w 2011 r. zysk netto wyniósł 829,14 mln zł, natomiast w 2012 r. wyniósł on 259,60 mln zł). Różnice w tym zakresie (poza nietypowym rokiem 2011) były do pewnego stopnia spowodowane polityką sukcesywnego zwiększania podaży drewna prowadzonej przez LP, co przekładało się na zwiększone przychody ze sprzedaży drewna, a to z kolei generowało zwiększone zyski. Ponadto pomimo pozytywnych zmian zapoczątkowanych w 2014 r. środki finansowe przeznaczane przez LP na hodowle 
i ochronę lasu, czyli nakłady o zasadniczym znaczeniu dla utrzymania i powiększania zasobów i ekosystemów leśnych, w 2018 r. były nadal dużo niższe od kosztów działalności administracyjnej, co zwiększa ryzyko nieosiągnięcia zasadniczych celów działania LP, jakimi są w szczególności utrzymanie oraz powiększanie zasobów i upraw leśnych, a także zachowanie i ochrona lasów oraz ekosystemów leśnych. W konsekwencji sposób prowadzenia gospodarki finansowej przez LP w dłuższej perspektywie czasowej może skutkować zaburzeniem równowagi pomiędzy produkcyjną funkcją lasu a funkcjami społecznymi, ekologicznymi oraz kulturowymi (NIK, 2015, s. 9). Z kolei wzrost wynagrodzeń w LP, które i tak zostały określone na dość wysokim poziomie (w latach 2011-2018 przeciętne wynagrodzenie miesięczne w LP prawie dwukrotnie przewyższało wysokość analogicznej kategorii wynagrodzeń w gospodarce narodowej), następowały w oderwaniu od zróżnicowania osiąganych wyników finansowych przez ten podmiot.

W badanym okresie analizowane działania realizowane przez LP zasadniczo wpisywały się w model prowadzenia trwale zrównoważonej gospodarki leśnej określony w ustawie o lasach. Jednakże pewne wątpliwości co do zgodności z podstawowymi celami funkcjonowania LP mogły budzić niektóre przejawy działalności inwestycyjnej bezpośrednio niezwiązane z gospodarką leśną. Wyniki kontroli NIK wykazały, że w niektórych obszarach, zwłaszcza tych skorelowanych z ponoszeniem nakładów na budowę środków trwałych, zasada racjonalnego gospodarowania środkami publicznymi nie zawsze miała pełne zastosowanie. W celu praktycznej implementacji tej zasady podstawą prowadzenia działalności inwestycyjnej LP powinien być rachunek ekonomiczny, a podejmowanie wszelkich przedsięwzięć inwestycyjnych powinno być poprzedzone dokonaniem odpowiednich analiz ekonomicznych, zwłaszcza że głównym zadaniem tej instytucji jest prowadzenie trwale zrównoważonej gospodarki leśnej w lasach stanowiących własność Skarbu Państwa.

\section{Bibliografia}

Bieluk J., Leśkiewicz K. (2017). Ustawa o lasach. Komentarz, Warszawa: Wydawnictwo C.H. Beck. ISBN 9788325599041.

Habuda A., Radecki W. (2016). Zarzadzanie lasami. W: A. Habuda (red.), Polskie prawo leśne, Warszawa: Wydawnictwo Difin, s. 263-292. ISBN 9788380851245. 
Dyduch J. (2016). The use of the Forest Fund in the protection of natural resources in Poland. Ekonomia i Środowisko 4 (59), s. 76-86. ISSN 0867-8898.

Dyrekcja Generalna Lasów Państwowych (2019). Sprawozdanie finansowo-gospodarcze za 2018 rok. Pobrane z: https://bip.lasy.gov.pl/pl/bip/finanse (dostęp 12.02.2020).

Główny Urząd Statystyczny (2019). Rocznik Statystyczny Leśnictwa 2019, Warszawa: Zakład Wydawnictw Statystycznych. Pobrane z: https://stat.gov.pl/obszary-tematyczne/roczniki-statystyczne/roczniki-statystyczne/rocznik-statystyczny-lesnictwa-2019,13,2.html (dostęp 12.02.2020).

Kosikowski C. (2006). Sektor finansów publicznych w Polsce, Warszawa: Dom Wydawniczy ABC. ISBN 8374165898.

Kropiewnicka M., Ostrowiecki D. (2014). Zmiany w Lasach Państwowych. Analiza modelu gospodarki leśnej w Polsce. W: B. Rakoczy, M. Szalewska, K. Karpus (red.), Prawne aspekty gospodarowania zasobami środowiska. Korzystanie z zasobów środowiska, Toruń: Wydawnictwo TNOiK „Dom Organizatora”, s. 221-230. ISBN 9788372857675.

Kruk H. (2017). Wybrane metody oceny zrównoważenia gospodarki leśnej. Optimum. Studia Ekonomiczne 4 (88), s. 171-186. ISSN 1506-7637.

Maćkowiak E. (2016). Finansowe podstawy działalności Państwowych Gospodarstw Leśnych Lasy Państwowe, Problemy Zarządzania 14/4 (1), s. 113-122. ISSN 16449584.

Najwyższa Izba Kontroli (2015). Gospodarka finansowa Lasów Państwowych. Pobrane z: https://www.nik.gov.pl/plik/id,9302,vp,11524.pdf (dostęp 12.02.2020).

Pakuła J. (2011). Pojęcie i zasady gospodarki leśnej. W: B. Rakoczy (red.), Wybrane problemy prawa leśnego, Warszawa: Wolters Kluwer Polska, s. 79-95. ISBN 9788326406614 .

Piekutin J. (2006). Analiza funkcjonowania funduszu leśnego w systemie finansowym Lasów Państwowych na przykładzie Regionalnej Dyrekcji Lasów Państwowych w Radomiu, Sylwan 6, s. 3-18.

Piekutin J., Gruchała A. (2006). Miejsce i rola funduszu leśnego w systemie finansowym Lasów Państwowych. Sylwan 2, s. 37-45. ISSN 0039-7660.

Radecki W. (2017). Ustawa o lasach. Komentarz, Warszawa: Wydawnictwo Wolters Kluwer Polska. ISBN 9788325599041.

Rakoczy B. (2018). Gospodarka leśna i trwale zrównoważona gospodarka leśna $w$ prawie polskim, Warszawa: Wydawnictwo Wolters Kluwer Polska. ISBN 9788381246590. 
Sadowska B. (2016). System pomiaru dokonań w Państwowym Gospodarstwie Leśnym Lasy Państwowe - proces przygotowania i implementacji. W: R. Kowalak, M. Kowalewski, P. Bednarek (red.), Wyzwania w zarządzania kosztami i dokonaniami, Prace Naukowe Uniwersytetu Ekonomicznego we Wrocławiu 442, s. 399-407. ISSN 1899-3192.

Szczypa P. (2016). Istota i rodzaje pożądanych zmian w rachunkowości Lasów Państwowych, Studia Ekonomiczne. Zeszyty Naukowe Uniwersytetu Ekonomicznego w Katowicach 300, s. 174-182. ISSN 2083-8611.

Szołno-Koguc J. (2007). Funkcjonowanie funduszy celowych $w$ Polsce $w$ świetle zasad racjonalnego gospodarowania środkami publicznymi, Lublin: Wydawnictwo UMCS. ISBN 9788322726457.

Szramka H., Adamowicz K. (2017). Kierunki modyfikacji statusu Lasów Państwowych $w$ Polsce, Sylwan, nr 161 (5), s. 355-364. ISSN 0039-7660.

Tyburek M. (2011). Status prawny i zadania Państwowego Gospodarstwa Leśnego Lasy Państwowe. W: B. Rakoczy (red.), Wybrane problemy prawa leśnego, Warszawa: Wolters Kluwer Polska, s. 118-145. ISBN 9788326406614. 
